\title{
A PRODUÇÃO DO ESPAÇO E DA PAISAGEM DA AVENIDA EPITÁCIO PESSOA, JOÃO PESSOA - PB
}

\section{THE PRODUCTION OF SPACE AND LANDSCAPE OF EPITÁCIO PESSOA AVENUE - JOÃO PESSOA - PB}

v. 7, n. 10

jan/ago (2015)

ISSN 1982-0569
Paula Dieb Martins

Universidade Federal da Paraíba e-mail: pauladieb@hotmail.com

Doralice Sátyro Maia

Universidade Federal da Paraíba e-mail: doralicemaia@hotmail.com

\section{Resumo}

A Avenida Epitácio Pessoa, localizada na cidade de João Pessoa-PB, no Nordeste Brasileiro, apresentou desde a sua abertura, no início do século XX, uma série de transformações até se tornar uma das principais ruas da cidade. O presente texto tem como objetivo analisar 0 processo de produção do espaço e da paisagem da referida via ao longo das primeiras décadas de sua ocupação relacionando-a com a dinâmica do espaço intraurbano de João Pessoa. Para a composição histórica e análise de tal processo foram utilizados de mapas, fotografias, notícias de jornais da época, memórias de profissionais que atuaram na avenida, assim como, informações já levantadas por pesquisadores. Observa-se que, até o final da década de 1950, a transformação da paisagem da avenida resultou na formação de novos bairros de alta renda da cidade.

\section{Palavras-chave}

História Urbana, Paisagem, Avenida Epitácio Pessoa - João Pessoa.

\begin{abstract}
The Epitacio Pessoa Avenue, located in the city of Joao Pessoa - PB, in the brazilian Northeast, presented a serie of visual and functional changes throughout the 20th century, becoming one of its most important streets. The present paper aims to analyze the process of production of space and landscape of the referred avenue during the early decades of its occupation related with the dynamic of João Pessoa's urban space. Maps, photographs, newspapers, memories of professionals that worked on the avenue, such as informations from other researches were used in order to develop the historical composition and the referred analysis. Finally, it's observed that, until the decade of 1950, the landscape transformation of the avenue resulted on the composition of new high income neighborhoods in the city.
\end{abstract}

\section{Keywords}

Urban History, Landscape, Epitácio Pessoa Avenue - João Pessoa. 
Entre a minha chegada e hoje já se passaram duas ou mais cidades. A prova é que, confiando numa carona da Epitácio, tive de tirar a pé até o jornal sem ser reconhecido por um único contemporâneo. O movimento incessante de carros e de pessoas era todo de outros moradores, outra geração, para a qual a gente vai se sentindo um fantasma ou, na melhor das hipóteses, trambolho. (RODRIGUES, s.d., p.20).

A cidade é produto de um processo: produto do trabalho humano, ela contém não apenas a materialidade, mas funções, símbolos, movimento, imagens, formas, conteúdos, espaço e tempo. Aos olhos de quem a desvenda, ela se apresenta mais como um rascunho, do que como um texto: de interpretação difícil, algumas vezes sem coerência, borrada, ela possui muitas escritas - sobrepostas e justapostas - inacabadas. É sobre este "terreno" que o presente texto transita, buscando compreender este rascunho que, ao mesmo tempo em que dissimula e omite, traduz o espaço produzido e seu processo de produção.

Ao caminhar pela rua de uma cidade é possível visualizar como as pessoas a utilizam e porque o fazem daquele modo, que tipos de pessoas determinado espaço atrai, qual a sua história a partir das antigas edificações, entre outros aspectos.

Elemento morfológico fundamental da cidade, a rua expressa a vida urbana (CAPEL, 2002). Ela configura a cidade a partir de sua forma, de sua função, do seu uso, de sua apropriação, de seus conflitos e de sua diversidade (CARLOS, 2001). Deste modo, o estudo desta porção específica do espaço urbano permite a compreensão de processos e acontecimentos que se realizam na cidade.

Este texto tem como objeto de estudo a Avenida Epitácio Pessoa localizada na cidade de João Pessoa, no Nordeste brasileiro - que possui aproximadamente $5 \mathrm{~km}$ de extensão orientada pelo eixo leste - oeste e interliga dois polos de atratividade da cidade: o Centro e a orla marítima.

o Centro compreende uma área marcada pelo elevado índice de estabelecimentos comerciais, de serviços e institucionais, assim como pelo

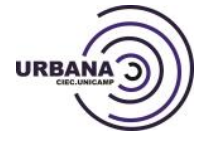

REVISTA ELETRONICA DO CENTRO INTERDISCIPLINAR DE ESTUDOS SOBRE A CIDADE . ISSN 1982-0569 v. 7, n. 10, jan /ago (2015). Dossiê História Urbana: a configuração de um campo conceitual 
acúmulo de funções depositadas e transformadas desde o início da ocupação da cidade. Já a orla - a aqui expressa -, corresponde à faixa litorânea dos bairros Cabo Branco ao sul e Tambaú ao norte. Caracteriza-se pela atratividade e variedade de serviços e comércio, de atividades de lazer, entretenimento e turismo, e pelo uso residencial da população de alta renda ${ }^{1}$.

Desde o início de sua abertura - como uma estrada -, no final da década de 1910, a Avenida Epitácio Pessoa tem sofrido diversas mudanças em relação à ocupação, aos usos, à paisagem e ao espaço produzido. A sua ocupação é um marco no processo de expansão de João Pessoa em direção à orla marítima ao longo do século $X X$, o qual transformou a antiga estrada em uma das principais avenidas da cidade.

De acordo com Coutinho (2004), a ocupação da mencionada via ocorreu de forma fragmentada e diversa ao longo do referido século. De fato, desde sua abertura até a década de 1950, raras foram as alterações sofridas em sua paisagem. O predomínio da Mata Atlântica ao longo do seu percurso foi aos poucos desaparecendo e dando lugar a loteamentos e conjuntos habitacionais a partir, principalmente, da década de 1950. Tais empreendimentos imobiliários estabeleceram-se conformando os novos bairros residenciais e conferindo uma realidade urbana inédita tanto para a avenida quanto para João Pessoa.

Com base nesses fatos, desenvolve-se 0 presente estudo com 0 objetivo de analisar como se deu a produção do espaço e da paisagem da Avenida Epitácio Pessoa ao longo do seu processo de ocupação inicial, ocupação esta que será modificada décadas mais tarde quando a avenida passa a se caracterizar como um corredor comercial.

A produção do espaço é um processo e, portanto, trata da dimensão espaço-temporal. É ao mesmo tempo resultado e condição para a reprodução

\footnotetext{
${ }^{1}$ De acordo com a Topografia Social da cidade de João Pessoa (SPOSATI, 2009), os bairros litorâneos Cabo Branco, Tambaú, Manaíra e Bessa - estão entre os que apresentam maior percentual de população com renda acima de 10 salários mínimos. Disponível em: <http://www.joaopessoa.pb.gov.br/portal/wpcontent/uploads/2012/04/TOPOGRAFIA-SOCIAL-DE-JOAO-PESSOA_2009.pdf> Acesso em: 05 mai. 2014.
}

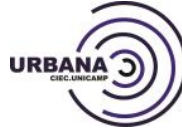

REVISTA ELETRONICA DO CENTRO INTERDISCIPLINAR DE ESTUDOS SOBRE A CIDADE . ISSN 1982-0569 v. 7, n. 10, jan /ago (2015). Dossiê História Urbana: a configuração de um campo conceitual 
da sociedade, isto é, das suas relações que se manifestam na prática espacial (LEFEBVRE, 1991).

Sendo assim, para a análise da produção do espaço da referida via é imprescindível o entendimento da sua situação na produção do espaço da cidade onde ela se localiza. Desta forma, abordar a Avenida Epitácio Pessoa, implica também em realizar uma breve leitura da história de João Pessoa, relacionando-a à produção do espaço e da paisagem da via.

Com base nos ensinamentos de Lefebvre (1991), Carlos (2007) e Villaça (1998), iniciaremos com o processo histórico da produção da cidade, identificando os marcos construídos e as principais intervenções nela realizadas. Para tanto, será utilizada não apenas a bibliografia relacionada aos referidos temas, mas também imagens, mapas e notícias de jornais da época, além de discursos de políticos e técnicos envolvidos em tal empreendimento urbano.

\section{A Evolução Urbana de João Pessoa e a abertura da Avenida Epitácio Pessoa}

Desde os primeiros séculos de sua fundação, João Pessoa teve sua área limitada pelas unidades morfológicas que the deram origem, margeadas pelo Rio Sanhauá e pelo Baixo Planalto Costeiro. Até o século XIX, a vida social da cidade tinha pouco dinamismo, era uma configuração intermediária do campo, ao qual ela ainda estava muito vinculada - graças às produções agrícola e pecuária -, cabendo à mesma as funções administrativa, religiosa e comercial. Neste período, a cidade ainda se caracterizava como "histórica ou tradicional" (Fig. 01), isto é, ainda se concentrava nas duas referidas unidades morfológicas e se organizava em torno dos bairros e das igrejas (MAIA, 2000).

Somente após a segunda metade do século XIX, a cidade, então denominada Parahyba do Norte, passou a ultrapassar os limites da área que vinha sendo ocupada desde o século XVI: nesse momento surgiram as primeiras ocupações em direção ao litoral, constituídas por sítios e chácaras

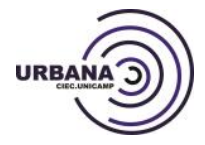

REVISTA ELETRONICA DO CENTRO INTERDISCIPLINAR DE ESTUDOS SOBRE A CIDADE . ISSN 1982-0569 


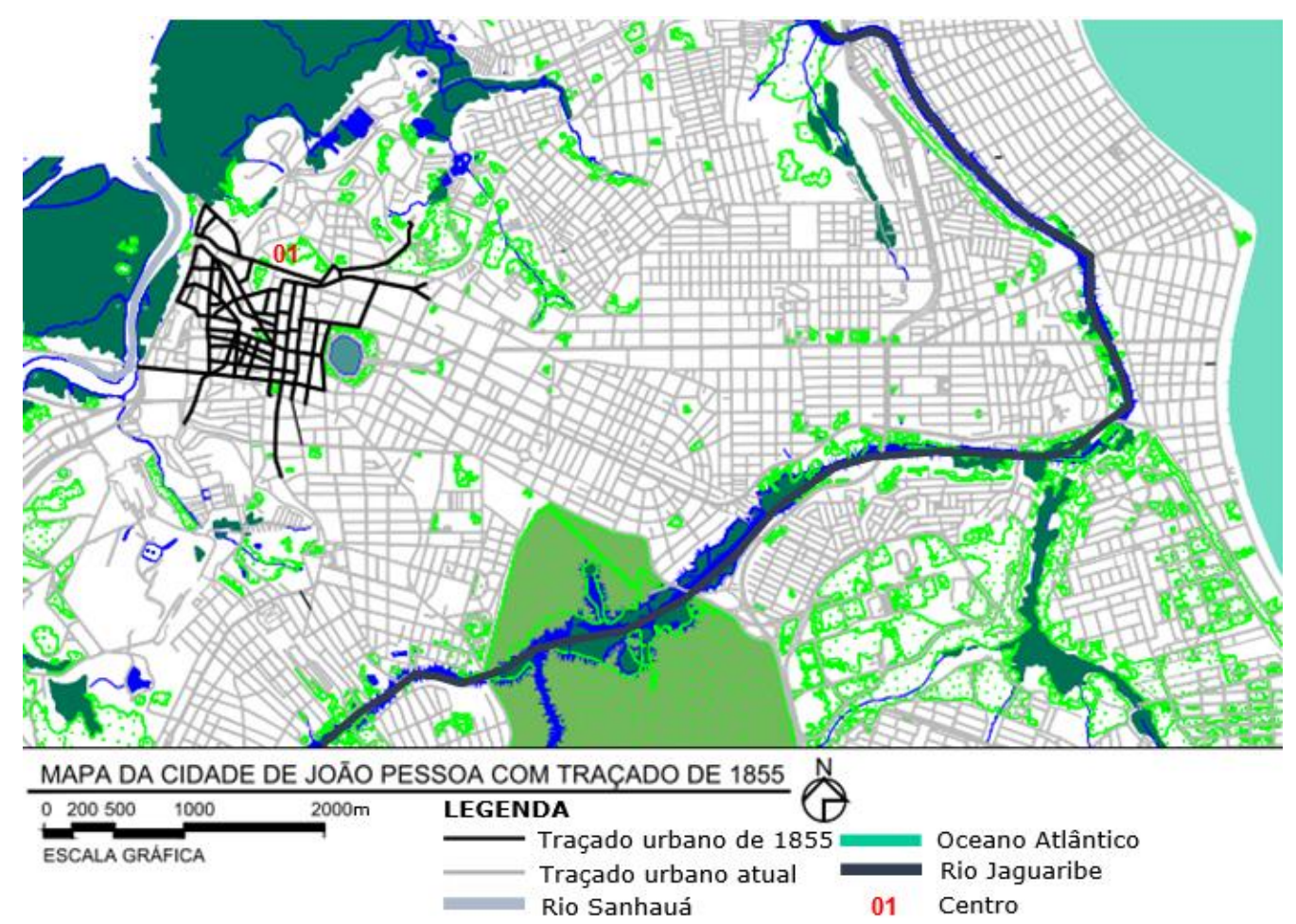

Figura 01 - Mapa atual de João Pessoa com sobreposição do traçado urbano de 1855 Fonte: "Planta da Cidade da Parahyba de 1855" (Acervo do Instituto Histórico e Geográfico da Paraíba IHGP) e "Planta Base da Cidade de João Pessoa" (Prefeitura Municipal de João Pessoa - PMJP). Edição do autor (2013).

A partir do século XIX, ocorreu uma série de mudanças no âmbito político, econômico e social, que por sua vez, deu início a um período de transformação do cenário urbano brasileiro. Acontecimentos como a Independência do Brasil (1822), a criação da Lei de Terras (1850), a abolição da escravatura (1888), a Proclamação da República (1889), a alta comercialização do algodão, assim como a substituição dos engenhos por usinas, fizeram com que as cidades assumissem uma nova posição no cenário econômico e político do país, quando parte da população do campo passou a residir nas mesmas, especialmente a elite agrária, constituindo uma elite urbana que, aos poucos, iria inserir na sociedade novos valores, em detrimento daqueles pregados pelas antigas oligarquias rurais. Este processo de passagem

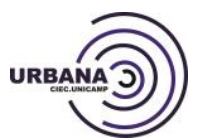

REVISTA ELETRONICA DO CENTRO INTERDISCIPLINAR DE ESTUDOS SOBRE A CIDADE . ISSN 1982-056 v. 7, n. 10, jan /ago (2015). Dossiê História Urbana: a configuração de um campo conceitual 
de uma sociedade escravocrata para uma sociedade de trabalho livre e a institucionalização da terra como propriedade - símbolo de poder político e econômico - se fizeram necessários pela instituição do modo capitalista de produção.

No início do século $\mathrm{XX}$, as reformas empreendidas pelo prefeito Pereira Passos, na então capital da república - o Rio de Janeiro -, tornaram-se um modelo de progresso e modernização urbana nacional, sendo prontamente seguido por outras capitais brasileiras, como Recife e Salvador, que - sob o trinômio sanear, circular e embelezar - alinharam e alargaram suas vias, instalaram sistemas de esgotos, abastecimento de água e energia elétrica, abriram praças e passeios arborizados, reformaram prédios e fachadas e prepararam o solo urbano para a expansão territorial e populacional com a abertura de novas vias e a criação de novos bairros.

Neste momento, muitas cidades passaram a ser alvo de uma série de investimentos do poder público a fim de negar seu passado colonial, se tornar vitrine da modernidade e do progresso republicano e se aproximar do modelo urbano de cidade europeia então em voga - Paris. Neste contexto, a cidade de João Pessoa não fica de fora: as reformas nela empreendidas no início do século XX objetivaram transformá-la em uma "cidade modernizada"2, marcada pela expansão territorial, pela desconcentração do seu centro tradicional e surgimento de novas centralidades, assim como pela diversificação de atividades e interesses sociais (MAIA, 2000).

A modernidade, conceituada por Berman (2007) como um conjunto de experiências vivenciadas pela humanidade de diversas formas desde o século XIX, se mostra e se desenvolve na sociedade ocidental a partir de uma série de mudanças e processos, em que se destacam a modernização e o modernismo. A modernização corresponde ao processo constante e contínuo

\footnotetext{
2 Esta "cidade modernizada" não deve ser confundida com a "cidade moderna" que, de acordo com Benevolo (1983), se caracteriza como aquela constituída por grandes elementos morfológicos (quadras, lotes, edifícios, ruas) compreendendo um conjunto unitário do ponto de vista construtivo/formal, sendo ela previamente planejada e projetada.
} 
de reestruturação social decorrente da dinâmica geográfica e dos modos de produção. Já o modernismo compreende o rebatimento cultural e ideológico desta modernização.

Portanto, pode-se dizer que a experiência da modernidade envolve não apenas elementos técnicos, científicos e espaciais, mas também a cultura, os valores e o comportamento da sociedade. Deste modo, tal experiência ocorre de forma diversificada de acordo com a realidade do local onde ela acontece:

Num polo, podemos ver o modernismo das nações avançadas, brotando diretamente da modernização política e econômica e obtendo visão e energia de uma realidade modernizada [...] mesmo quando desafia essa realidade de forma radical. No polo oposto, encontramos um modernismo que emerge do atraso e do subdesenvolvimento. [...] O modernismo do subdesenvolvimento é forçado a se construir de fantasias e sonhos de modernidade, a se nutrir de uma intimidade e luta contra miragens e fantasmas. Ele se dobra sobre si mesmo e se tortura por sua incapacidade de, sozinho, fazer a história, ou se lança a tentativas extravagantes de tomar para si toda a carga da história. (BERMAN, 2007, p. 271).

A "modernidade" brasileira foi responsável por transformações radicais em suas principais cidades e na sua população, as quais, até então, se encontravam praticamente diante de uma realidade colonial dos séculos XVI, XVII e XVIII. Nestas cidades, "o desenvolvimento da modernidade não se dá como consequência do crescimento industrial e sim graças ao processo mundial de modernização dos espaços físicos, dos hábitos e dos costumes da população citadina" (SÁ, 2009, p.124). As transformações nelas empreendidas compreenderam violentas reformas urbanas que modificaram traçados, desalojaram famílias, demoliram edifícios públicos, privados e institucionais, como as Igrejas, para implantação de novas praças e ruas mais largas - no caso de João Pessoa.

$\mathrm{Na}$ cidade estudada, é através da instituição de ações, órgãos fiscalizadores e legislação urbana, que o espaço de dominação se impõe. Tal espaço resulta no controle, ordenamento e imposição de um modelo urbanístico importado de uma realidade urbana completamente diferente, a

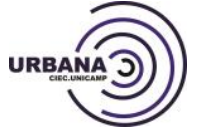

REVISTA ELETRONICA DO CENTRO INTERDISCIPLINAR DE ESTUDOS SOBRE A CIDADE . ISSN 1982-0569 v. 7, n. 10, jan /ago (2015). Dossiê História Urbana: a configuração de um campo conceitual 
CIEC

qual transforma não apenas o espaço físico da cidade, mas também o seu imaginário e a vida social da sua população.

De acordo com Carlos (2007), o espaço corresponde a uma estrutura que resulta de movimentos de dominação e apropriação, ele deriva tanto das estratégias políticas e econômicas quanto das práticas sociais que nele tomam forma. Partindo-se desta perspectiva e identificando-se tais estratégias e seus rebatimentos sociais, a leitura da cidade torna-se complexa e o espaço perde sua neutralidade e determinismo.

Ao estudar as diversas intervenções sofridas pela cidade nas quatro primeiras décadas do século XX, Vidal (2004) dividiu-as em dois tipos aquelas que agem no tecido urbano existente e aquelas que promovem a expansão urbana.

As primeiras melhorias da cidade passaram a ser efetuadas a partir da década de 1910 - quando foi implantado o serviço de abastecimento de água, o fornecimento de energia elétrica e os bondes começaram a ser convertidos para a tração elétrica - tendo seu auge na década de 1920.

Vale ressaltar ainda a criação, em 1906, da Ferrovia de Tambaú, a qual, a partir de 1911 , teve seu trajeto totalmente finalizado, passando a conectar a cidade à orla. Tal melhoramento, por sua vez, possibilitou melhor acesso à praia de Tambaú transformando-a aos poucos num polo de veraneio e local de lazer da população (RODRIGUEZ, 1994).

A década de 1920, caracterizou-se como um momento de grande efervescência política e sociocultural, com a consolidação de conceitos/modelos representativos da modernização adotados em diversas capitais brasileiras e, também, pela prosperidade econômica gerada pela grande demanda internacional da fibra de algodão - escassa nos países europeus no período pós-primeira guerra mundial. Neste momento, foi criado um instrumento de legislação urbana - o Decreto $n^{\circ} 32$ de 4 de janeiro de $1921^{3}$ - e formado um

\footnotetext{
${ }^{3}$ De acordo com Vidal (2004), este decreto consistia na delimitação das áreas urbanas e suburbanas e instituía um código com normas disciplinadoras para as futuras construções tais espaços.
} 
corpo técnico responsável pela sua regulamentação e controle e, também, foi idealizada e iniciada a abertura da Avenida Epitácio Pessoa.

Apesar da qualidade do algodão produzido na época, o Estado da Paraíba carecia de vias de acesso adequadas para o transporte do produto - o mesmo era transportado por animais de carga, perdendo assim qualidade e quantidade ao longo dos extensos e inadequados percursos - e sua infraestrutura portuária era precária para atender aos interesses econômicos locais. Desta forma, o governo paraibano investiu na implantação de ferrovias e, posteriormente, rodovias que canalizassem a produção para os demais Estados (GUEDES, 2006). Inserida neste projeto do governo estava a abertura da Avenida Epitácio Pessoa, como via que conectaria a cidade a um novo porto a ser instalado na praia de Tambaú:

No mez de abril, indo ao encontro de uma Idea predominante, qual a de se fazer na enseada de Tambaú o nosso ancoradouro externo, iniciei os trabalhos de uma avenida de 4862 metros de extensão por 36 de largura ligando a Capital áquelle ponto do littoral. (Mensagem do Governador Camillo de Hollanda, 1917, p.39).

A abertura da referida via, iniciada no governo de Camillo de Holanda (1916-1920), não chegou a ser concluída pelo mesmo e, o porto não foi construído devido a uma série de fatores, inclusive às especificidades naturais da praia de Tambaú que impediam sua instalação:

AVENIDA EPITÁCIO PESSOA - Logo no comêço da administração pensámos como necessidade da capital no plano de tres grandes estradas de rodagem, uma ligando esta cidade ao Recife, para attender aos multiplos interesses de ambos; outra, ligando directamente a capital a Mamanguape, que se podia converter em notavel celleiro do Estado; a terceira, ligando a capital á praia de Tambaú, onde se cogitava de construir o porto do Estado. As duas primeiras só podiam ser feitas com a collaboração do Govêrno Federal que actualmente cogito do assumpto. A ultima, que é a avenida Epitacio Pessôa, tratámos de levar a effeito, mas circumstancias imprevistas não nos permittiram conclui-la, estando, entretanto, trabalhado um grande trecho, onde se fez preciso considerável movimento de terra, derrubadas de mattas, etc. Esse trecho vae alem do Tambaúsinho na extensão de alguns kilometros servido pela linha de bonde electrico, não existindo ainda trafego regular. A avenida foi projetada linha dupla, havendo ao centro espaços para 
arborisação com refúgios, permittindo também a arborisação lateral, transito de vehiculos e peões. (Exposição do Governador Camillo de Holanda, 1920, p. 20).

Apesar disso, percebe-se que em seu discurso no final do mandato, Camillo de Holanda, demonstra ainda um esforço e interesse pela finalização das obras da avenida, mesmo que a ideia de implantação do porto já estivesse fora de cogitação. O crescimento populacional e econômico, o desenvolvimento da indústria e dos transportes urbanos, assim como a formação de uma burguesia urbana e do ideal de modernização e progresso, que regiam as cidades brasileiras da época, enfatizaram a necessidade da abertura da Avenida Epitácio Pessoa que, por sua vez, adquiriu um novo propósito: conformar um grande eixo de circulação e expansão da cidade (VIDAL, 2004).

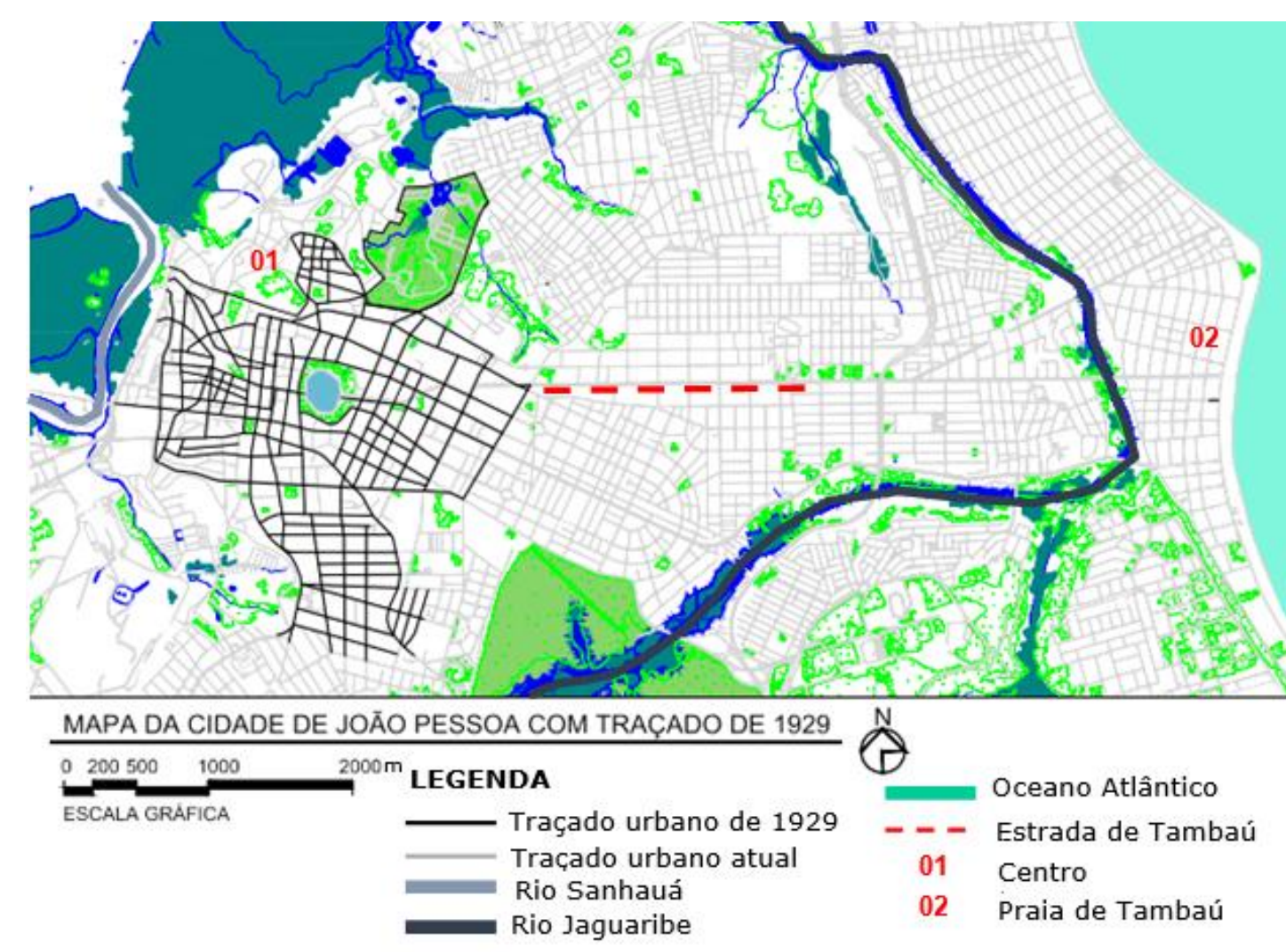

Figura 02 - Mapa atual de João Pessoa com sobreposição do traçado urbano de 1929 Fonte: "Planta da Cidade da Parahyba de 1929" (Acervo IHGP) e "Planta Base da Cidade de João Pessoa" (PMJP). Edição do autor (2014). 
Dada uma série de dificuldades financeiras, a obra de abertura da avenida que havia sido iniciada no final da década de 1910, só foi retomada na década de 1930 (Fig. 02), no governo de Gratuliano de Brito (1932-1934), utilizando os recursos das obras contra a seca durante a gestão do então presidente Epitácio Pessoa, e finalizada - atingindo a orla marítima - na década de 1940 (SILVEIRA, 2004).

\section{As primeiras ocupações da Avenida Epitácio Pessoa}

Com a abertura da avenida e a instalação da linha de bonde, a praia passou a ser frequentada com mais assiduidade pela população. Até então, as áreas litorâneas eram utilizadas apenas durante o veraneio pelas camadas de alta renda, as quais possuíam uma casa na cidade e outra na praia. Neste período foi perceptível a mudança de apreciação das praias que, segundo Silva (2001), antes eram tidas como locais malsãos e, a partir de meados do século XX - devido principalmente aos discursos médicos - passaram a ser vistas como locais de amenidades, adquirindo valor residencial.

Localizada no final do trajeto da Avenida Epitácio Pessoa, a praia de Tambaú 4 era ocupada, até o início do século $X X$, apenas por uma comunidade de pescadores, que tinha como sustento a pesca e a extração do coco, e por um grupo de franciscanos, que lá construíu uma capela e uma missão para catequizar os membros da comunidade que ali habitava. Por apresentar focos de malária e charcos, a ocupação da área pela população que vinha do Centro ocorreu lentamente a partir do referido período, à medida que obras de melhoramentos passaram a ser executadas em tal região (LEITÃo, 1998).

Ainda no final da década de 1920, a ocupação da orla despertou o interesse da Prefeitura e de um proprietário de terras da área: neste momento

\footnotetext{
${ }^{4}$ Apesar da abertura da Avenida Epitácio Pessoa ter possibilitado melhor acesso à praia, tal área não foi incorporada de pronto à malha urbana da cidade, como é possível visualizar na fig. 02, a qual não faz referência à sua ocupação. Na década de 1960, ela foi denominada Distrito de Tambaú (pela Lei $n^{\circ}$ 2.638, de 20 de dezembro de 1961) e a sua transformação em bairro realizou-se apenas através do Ato das Disposições Constitucionais Transitórias (Art. 65) na Constituição do Estado da Paraíba de 1989. (LEITÃO, 1998).
} 
foi loteada parte da gleba de Antônio Lyra localizada em Tambaú e foi confeccionada uma planta da cidade (em 1930) pelo engenheiro Alfredo Cihar, delineando o traçado urbano da ocupação inicial e das primeiras ruas projetadas (LEITÃO, 1998).

A mudança no modo de apreciação das áreas litorâneas transformou seu próprio conteúdo simbólico e suas representações que, por sua vez, influenciaram diretamente o processo de produção do seu espaço/paisagem. À medida que os discursos médicos se transformaram em práticas urbanas, a população passou a enxergar as praias como locais atrativos, voltando-se em sua direção (SILVA, 2001). A concretização da abertura da Avenida Epitácio Pessoa, assim como, as melhorias em seu acesso, irão destacar ainda mais a potencialidade desta nova via, aproximando cada vez mais a população da orla, a partir da ocupação dos loteamentos instalados ao longo de suas margens.

Dentre as diversas intervenções que promoveram a expansão urbana da cidade na direção leste e a ocupação da Avenida Epitácio Pessoa, destacase a urbanização da então Lagoa dos Irerês, que compreendia uma área alagadiça e foco de infecções, e constituía uma barreira à referida expansão. Tal obra, concluída em 1939, solucionou uma descontinuidade no traçado da cidade - compreendido entre o novo bairro Jaguaribe, localizado ao sul e o bairro de Tambiá, localizado a Nordeste -: após a sua finalização, foram implantados os bairros residenciais do Montepio ${ }^{5}$ e da Torre (Fig. 03 e 04), os quais representaram um avanço e consolidação da mancha urbana na direção leste (SILVEIRA, 2004).

Além da urbanização da Lagoa dos Irerês e dos melhoramentos estéticos e sanitários da área, foram abertas novas ruas, entre as quais se

\footnotetext{
${ }^{5}$ Atual Instituto de Previdência Social do Estado da Paraíba (IPEP), o Montepio foi uma instituição de financiamento de residências para a classe média (funcionários públicos e comerciantes). Inicialmente, na década de 1930, as primeiras casas construídas originaram o antigo bairro do Montepio - hoje inserido no perímetro do bairro de Tambiá. Posteriormente, foram realizados outros financiamentos de residências nos novos bairros da cidade até a década de 1970, quando a instituição foi transformada em IPEP, recebendo nova estruturação e atribuições (SILVEIRA, 2004).
} 
destacam a Avenida Getúlio Vargas e a Rua Corolário Soares de Oliveira que conectaram o novo Parque Solon de Lucena à Praça da Independência e à Avenida Epitácio Pessoa, criando novos caminhos e facilitando o deslocamento da população na direção leste (Fig. 05).

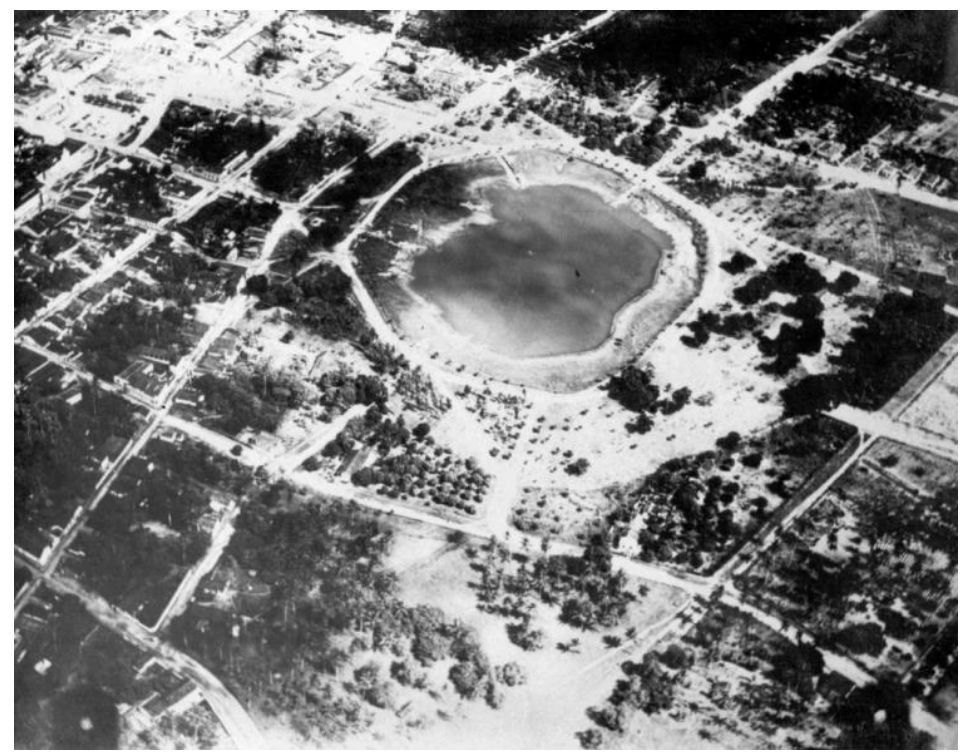

Figura 03 - Vista área da Lagoa e seu entorno antes da urbanização (data provável: 1920/1930) Fonte: Acervo Humberto Nóbrega.

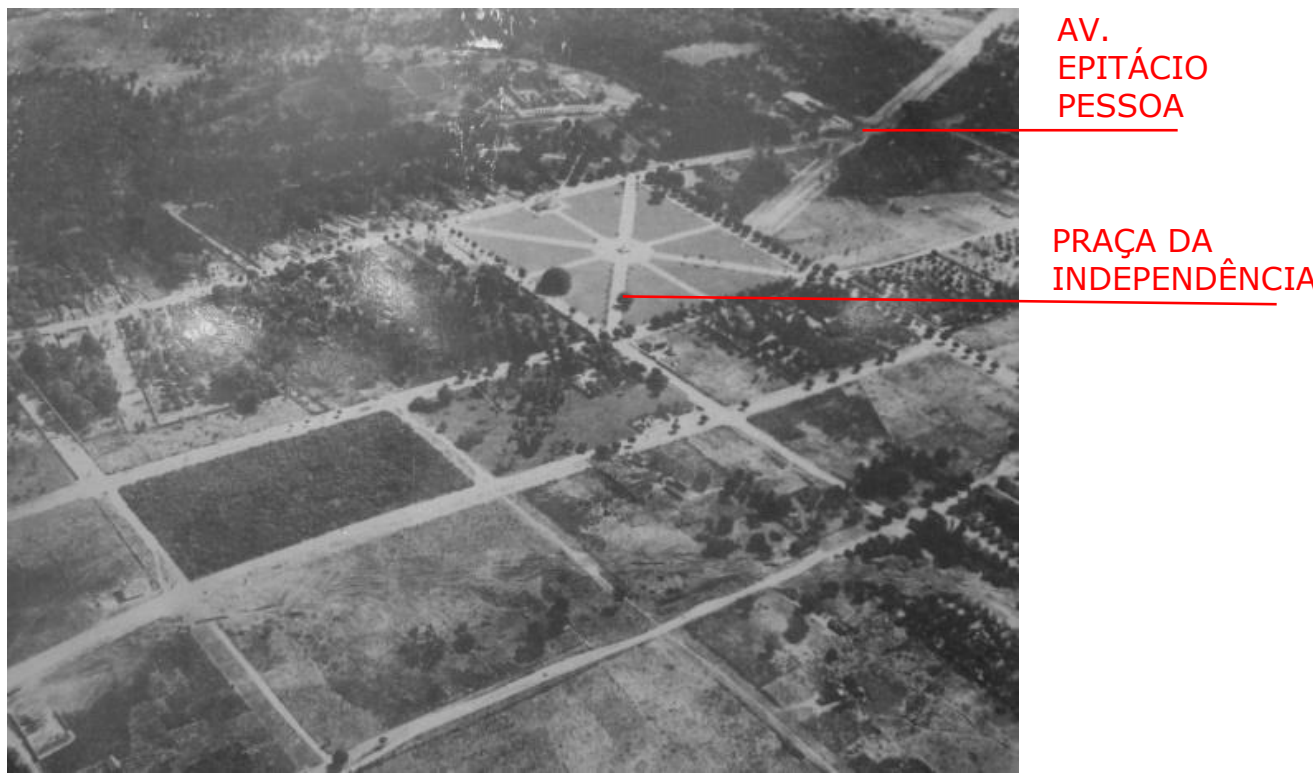

Figura 04 - Vista área da área da Praça da Independência e início da Avenida Epitácio Pessoa antes da urbanização da Lagoa dos Irerês (1934). Foto: Gilberto Stuckert

Fonte: Acervo Walfredo Rodriguez (Arquivo Histórico Waldemar Duarte). Edição do autor (2013). v. 7, n. 10, jan /ago (2015). Dossiê História Urbana: a configuração de um campo conceitual 


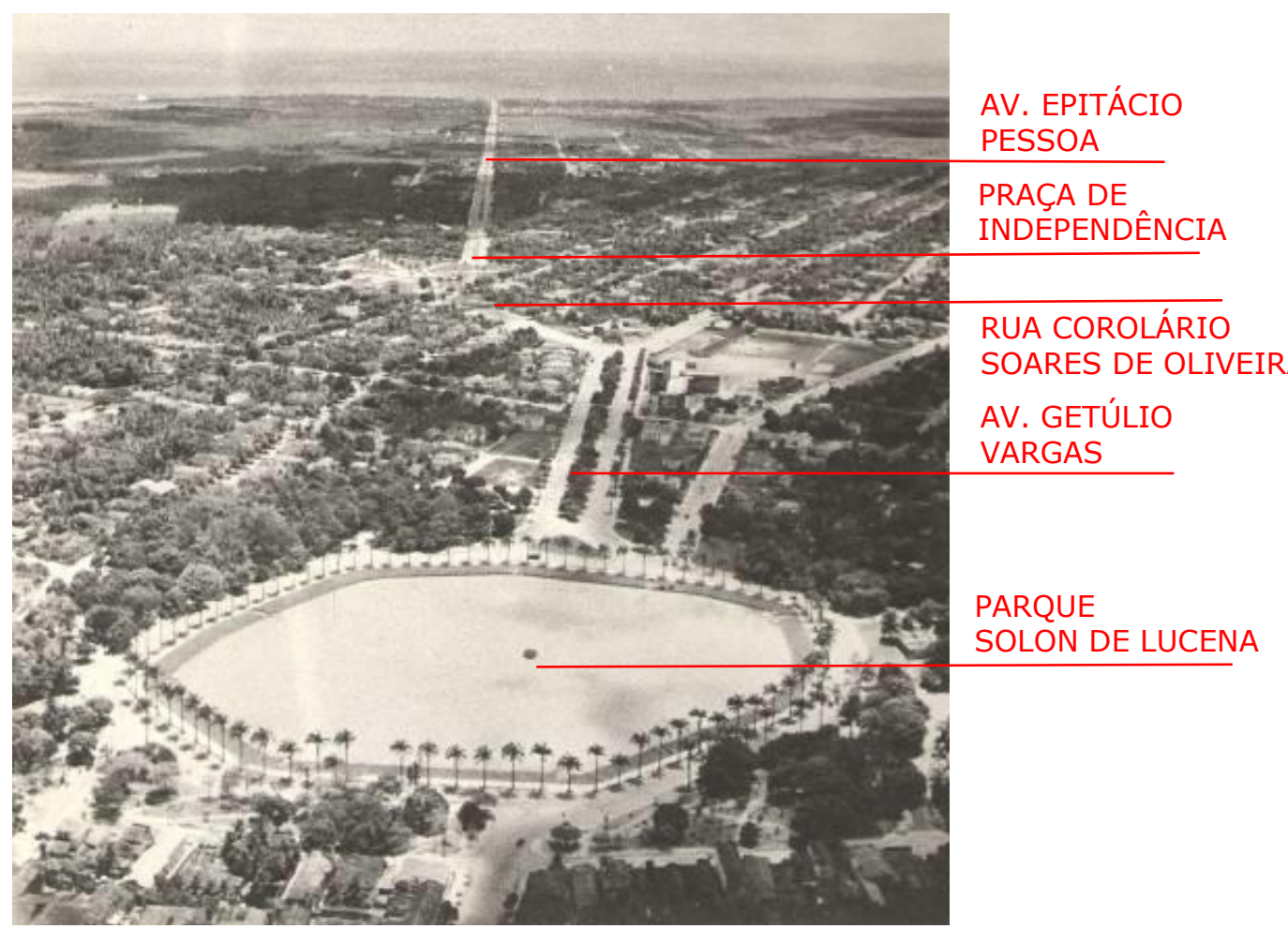

Figura 05 - Vista área da Lagoa e seu entorno urbanizado e ocupado (sem data). Acervo Humberto Nóbrega

Fonte: Vidal (2004, p. 81). Edição do autor (2013).

A Avenida Epitácio Pessoa, quando da finalização de sua abertura, em 1940, consistia ao longo de grande parte de sua extensão em um espaço inabitado, ocupado pela mata atlântica, composto por grandes glebas e alguns sítios, onde a agricultura era praticada com fracos rendimentos. A sua extremidade leste - praia de Tambaú - era pouco habitada, e a extremidade oeste, possuía as ocupações contíguas à área central da cidade - como as áreas próximas à Cruz do Peixe - em Tambiá - e o Bairro da Torre, como descreveu Medeiros (1994, p.26):

Cruz do Peixe ia terminar nas matas que ensombravam a estrada de Tambaú, verdadeira floresta, coito de pretos fugidos e malfeitores que, vez por outra, assaltavam os transeuntes, arrebatando-Ihes quanto conduziam. E a floresta tomava grandes proporções, especialmente antes do Sobradinho, na Cruz do Caboclo, onde se bifurcavam um caminho para Cabo Branco. Segundo a tradição mataram ali um caboclo foragido da Penha, após o assassinato que praticara para roubar o dono 
daquela propriedade. Assim, por longos anos, quem passava no local via, à margem do caminho, uma cruz de madeira indicando a sepultura do malfeitor.

O Bairro da Torre fez parte de um plano de remodelação e extensão para a cidade de João Pessoa 6 projetado pelo urbanista Nestor de Figueiredo na década de 1930, consistindo num bairro ocupado majoritariamente pela população de classe média.

A partir da análise de mapas das primeiras décadas do século $X X$, é possível constatar que entre as décadas de 1910 e 1940, a cidade estendeu seus limites territoriais numa velocidade inédita, quando a mesma chegou a ocupar uma área duas vezes mais extensa (Fig. 06). Paralelamente a esta expansão territorial, houve um aumento da população urbana, devido, entre outros fatores, às transformações ocorridas no meio rural no final do século XIX - como foi dito anteriormente -, que fizeram com que boa parte da população rural passasse a residir na cidade, principalmente as famílias mais abastadas do campo.

De acordo com Maia (2000), no início do século XX, o espaço urbano passa a ser reflexo da preponderância do espaço rural. Inicialmente, a área ocupada pela elite rural em João Pessoa foi a Avenida João Machado, aberta na década de 1910, fazendo parte da implantação do primeiro bairro planejado da cidade - Jaguaribe. A referida avenida, projetada como um boulevard ${ }^{7}$ - que representava um dos símbolos da cidade moderna -, teve seus extensos lotes ocupados por grandes e luxuosas residências (TRAJANO FILHO, 2006).

De fato, o projeto da Avenida Epitácio Pessoa também segue o modelo dos boulevards mundialmente conhecidos a partir do projeto do Prefeito Hausmann para Paris na segunda metade do século XIX, compreendendo

\footnotetext{
${ }^{6}$ Este plano, elaborado em 1932, tinha como objetivo melhorar a cidade existente e, ao mesmo tempo, planejar a cidade futura, ordenando sua expansão. Apesar de não ter sido completamente executado, suas diretrizes exerceram grande influência para a expansão de João Pessoa (VIDAL, 2004).

7 De acordo com Benevolo (1983), tal termo francês foi originalmente utilizado para definir uma coroa de avenidas arborizadas implantadas no lugar das antigas muralhas da Paris medieval.
} 
largas avenidas arborizadas. Como recorda o arquiteto Mário di Lascio ${ }^{8}$ década de 1950, foram plantadas nas calçadas e no canteiro central da avenida - na época com 6 metros de largura - centenas de árvores de médio porte, compondo um corredor verde ao longo do seu percurso.

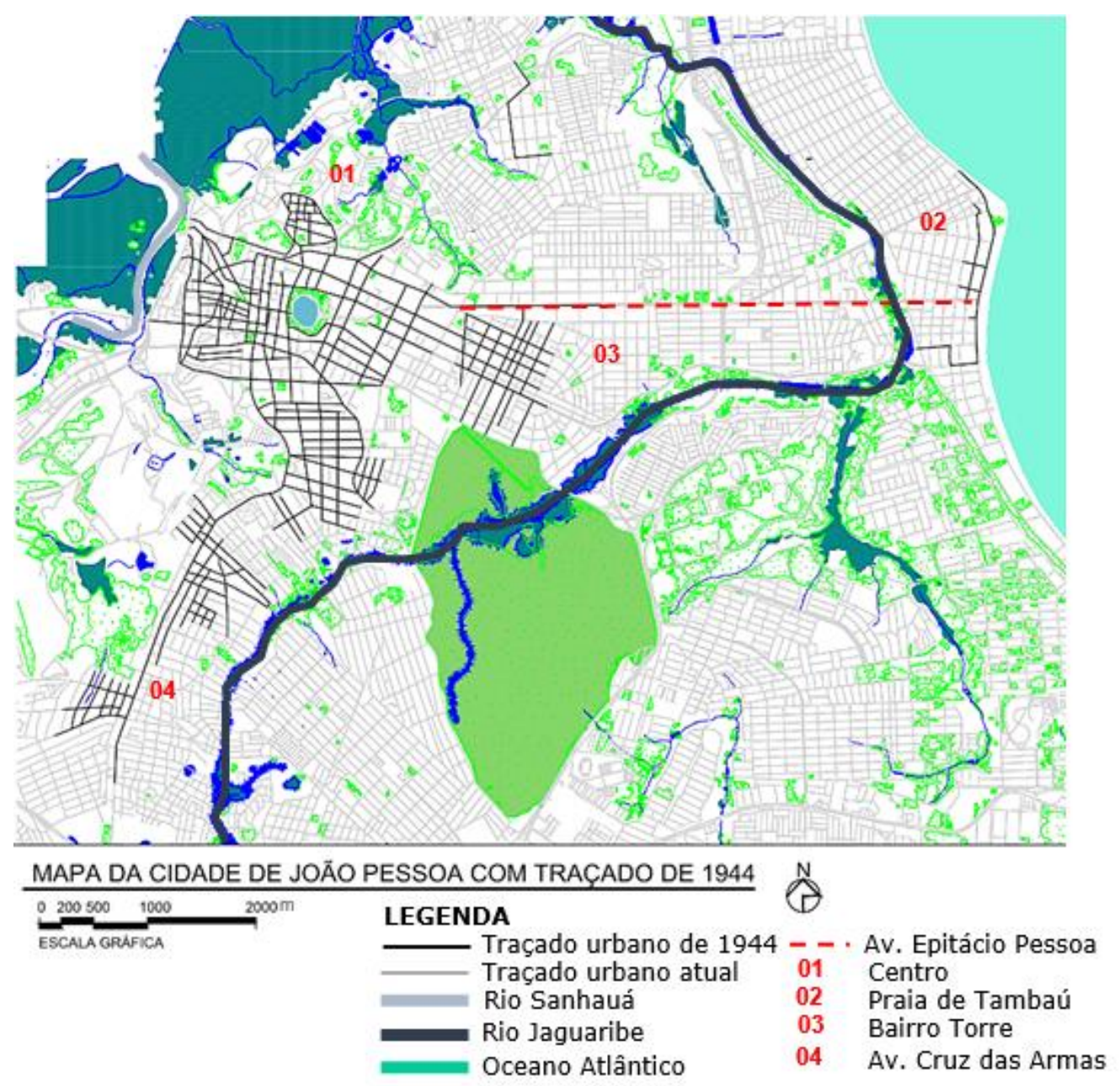

Figura 06 - Mapa atual de João Pessoa com sobreposição do traçado urbano de 1944 Fonte: "Planta da Cidade de João Pessoa de 1944" (Acervo da Biblioteca Nacional) e "Planta Base da Cidade de João Pessoa" (PMJP). Edição do autor (2014).

De acordo com Coutinho (2004), a partir da década de 1940, a paisagem da referida via passa a receber suas primeiras edificações, as quais consistiram nas residências do bairro da Torre e no quartel do $1^{\circ}$ Grupamento de Engenharia (Fig. 7), que possuía também uma vila para oficiais e um

${ }^{8} \mathrm{Em}$ entrevista realizada em 20 de fevereiro de 2013. 
hospital. Ainda nessa década, foi promulgada a primeira Lei Orgânica e o Código de Posturas do Município ${ }^{9} \operatorname{com}_{\text {a }}$ função de ordenar e controlar 0 crescimento urbano, concentrando-se na aprovação dos novos loteamentos a sul e leste da cidade.

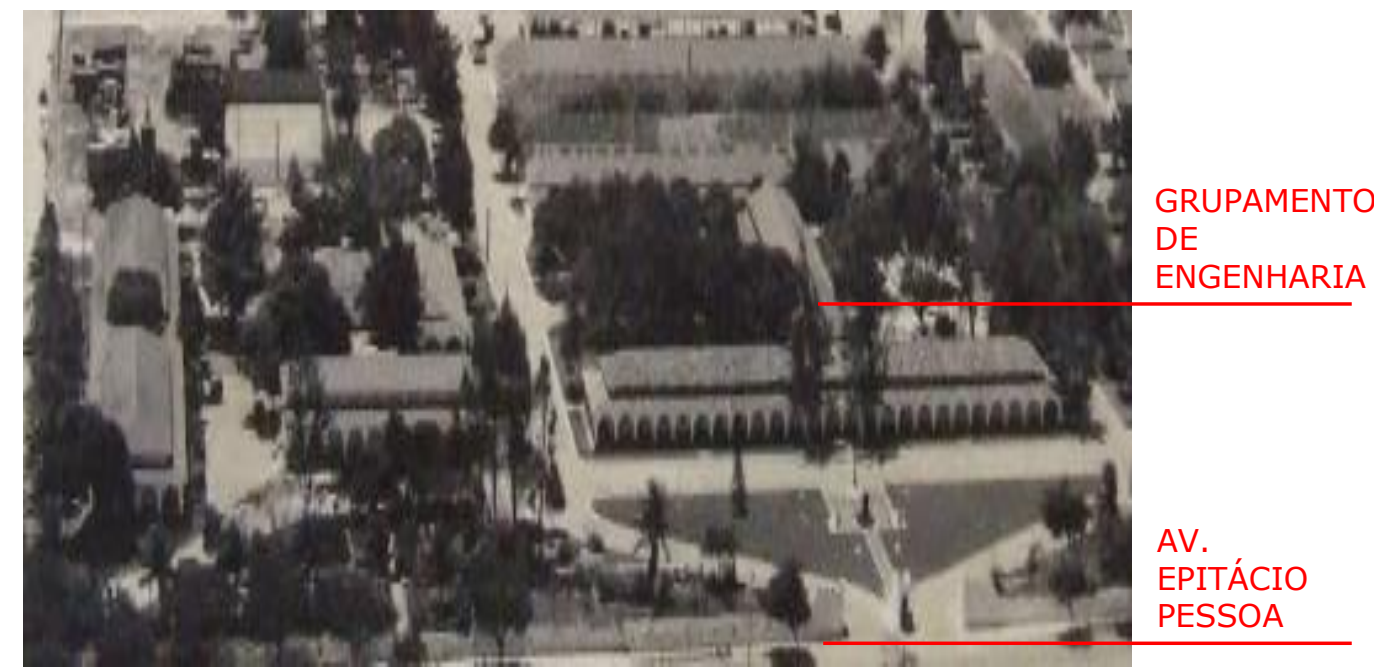

Figura 07 - Imagem do Grupamento de Engenharia (1968)

Fonte: Acervo Museu do Grupamento de Engenharia. Edição do autor (2013).

A partir deste momento, é possível visualizar o esforço por parte da iniciativa pública e privada a fim de controlar a expansão e a distribuição da população ao longo dessas novas áreas de expansão da cidade: favoreceu-se a instalação das camadas de alta renda a leste - ao longo do eixo da Avenida Epitácio Pessoa - e, ao mesmo tempo, induziu-se as classes populares para os setores de expansão na direção sul - ao longo do eixo da Avenida Cruz das Armas.

$\mathrm{Na}$ década de 1950, houve grande investimento por parte do poder público para a melhoria das condições infraestruturais das áreas "suburbanas" da capital do Estado (Fig. 08), visando aperfeiçoar as condições dos novos bairros e atrair a população para tais áreas. Durante o governo de José Américo de Almeida (1951-1955), foi criada uma Lei ( $n^{\circ} 570,10$ de outubro de

\footnotetext{
${ }^{9}$ Em 11 de outubro de 1948.
} 
1951), que autorizava o Governo Estadual a estabelecer um convênio com a Prefeitura de João Pessoa para contribuir com os melhoramentos da capital.

Os principais bairros residenciais desta Capital, com suas ruas e avenidas ornamentadas por uma arquitetura moderna, de há muito reclamavam pavimentação adequada que os libertasse da lama no inverno e da poeira no verão. (A UNIÃO, 31 jan. 1955, p.1).

Neste período, além da pavimentação das principais ruas da cidade, foi construída a ponte sobre o Rio Jaguaribe (Fig. 09) - na Avenida Epitácio Pessoa -, foram realizadas obras de terraplanagem, galerias, meio-fio e linhas de água e, para a cobertura da despesa de todos esses empreendimentos, foi realizado o loteamento do Campo de Aviação da Imbiribeira ${ }^{10}$, localizado às margens da referida via (A UNIÃO, 1955). O esforço do governo em melhorar a área foi bem descrito no trecho de uma notícia de jornal veiculado na época:

O plano de urbanização da Capital e, especialmente, a pavimentação de João Pessoa e de Tambaú, tem merecido a melhor atenção do Governador José Américo, que dirigiu sua ação no sentido de renovar o aspecto urbano da cidade, com um bom serviço de calçamento que vem beneficiando, inclusive, alguns bairros mais afastados, como o de Cruz das Armas e a avenida de ligação para Tambaú, abrangendo, assim uma vasta área e estimulando o surto de progresso ao longo da Avenida Epitácio Pessoa. (A UNIÃO, 31 jan. 1955, p.1).

No ano de 1952, a Avenida Epitácio Pessoa recebeu ao longo de toda sua extensão a pavimentação de paralelepípedos (Fig. 10 e 11). Tal fato, possibilitou a instalação e circulação dos bondes e marinetes e, posteriormente, de ônibus e automóveis no sistema de transporte urbano, proporcionando melhores condições de tráfego, acessibilidade e mobilidade em tal região da cidade. Neste período houve uma intensificação do processo de ocupação das margens da avenida, graças também ao lançamento de novos loteamentos ao longo da mesma.

\footnotetext{
${ }^{10}$ Com uma estrutura simples, o Campo de Aviação da Imbiribeira foi instalado em um trecho da Avenida - que corresponde atualmente a parte do bairro Tambauzinho -, durante o Governo de João Pessoa (1928-1930) (COUTINHO, 2004).
} 


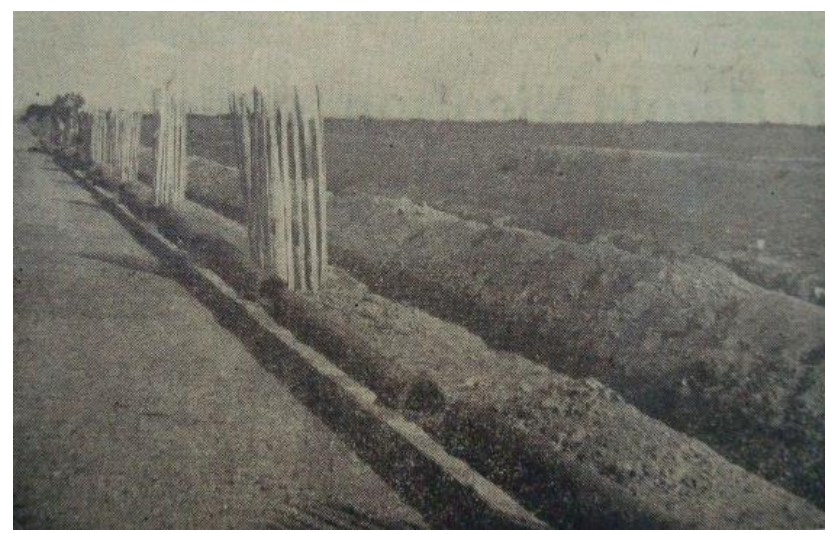

UNICAMP

Figura 08 - Imagem da obra de instalação da rede de abastecimento de água na avenida Epitácio Pessoa Fonte: A União (12 jan. 1955).

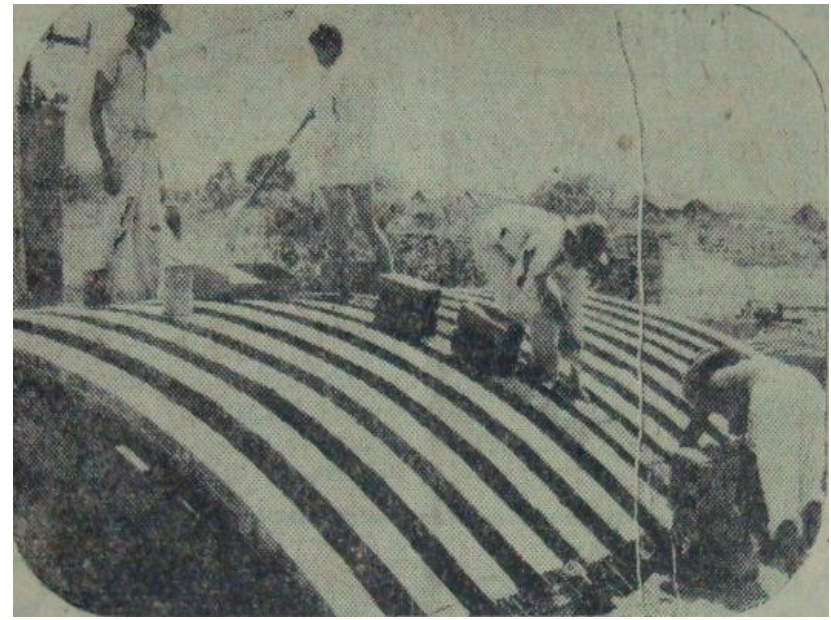

Figura 09 - Imagem da construção da ponte sobre o Rio Jaguaribe da Avenida Epitácio Pessoa Fonte: A União (22 out. 1952).

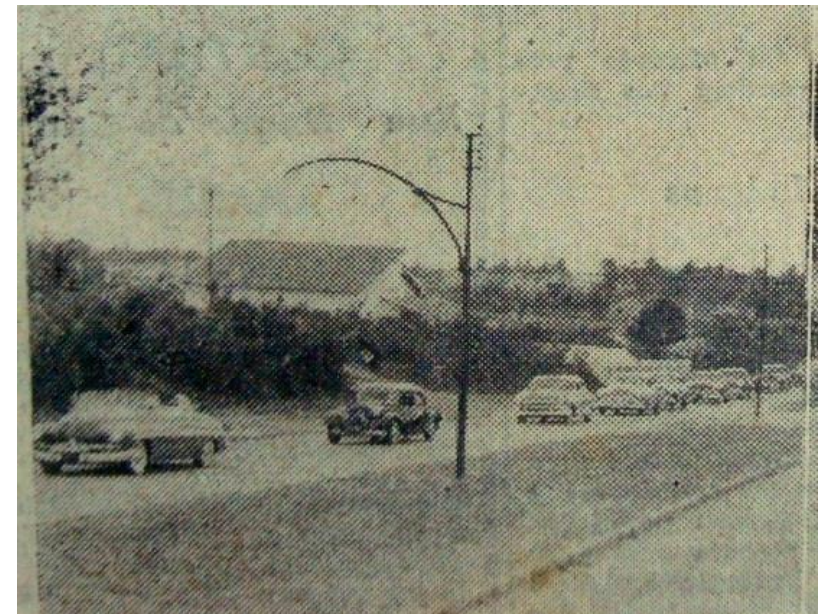

Figura 10 - Imagem da inauguração do calçamento da Avenida Epitácio Pessoa Fonte: A União (25 dez. 1952). 
A dominação do espaço pela população de alta renda e do unicamp empreendeu desta forma uma política em que os interesses públicos e privados complementaram-se: os melhoramentos urbanos geraram a valorização das grandes glebas que, por sua vez, foram loteadas e vendidas a um preço alto, apoiando-se nos discursos de cidade modernizada, crescimento urbano e estilo de vida moderno.

De acordo com Silveira (2004), a partir da década de 1950, iniciou-se o momento de criação e consolidação dos loteamentos das áreas adjacentes à Avenida Epitácio Pessoa, graças à implantação dos novos bairros de classe média e alta. Tal ocupação caracterizou-se pelo predomínio do uso residencial, que ocorreu de modo diversificado e fragmentado, apresentando em alguns trechos residências modernas e suntuosas e, em outros, residências mais simples, de conjuntos habitacionais.

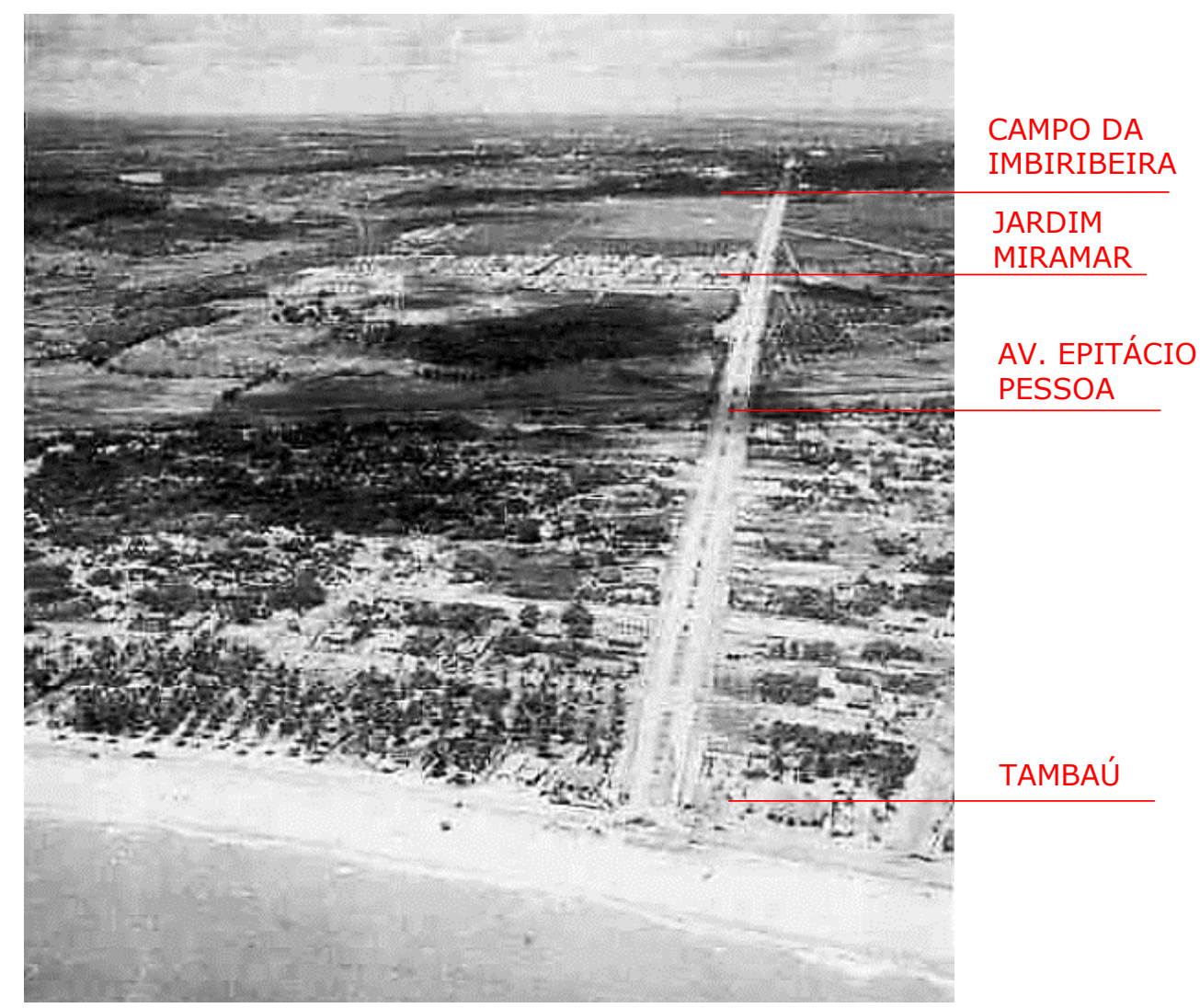

Figura 11 - Imagem aérea da cidade de 1955 - Acervo Humberto Nóbrega Fonte: Trajano Filho (2006, p. 42). Edição do autor (2013). 
Apesar do interesse pela área, a ocupação da Avenida Epitácio Pessoa não se deu de modo contínuo. Os loteamentos das glebas adjacentes a ela foram lançados aos poucos, assim como as suas novas construções, as quais se concentravam inicialmente em determinados trechos do percurso geralmente na proximidade do bairro da Torre e de Tambaú (TRAJANO FILHO, 2006). O quadro a seguir (Tabela 1) exibe a descontinuidade nos anos de lançamento dos loteamentos situados nas margens da avenida.

Tabela 1 - Loteamentos da avenida e seus respectivos anos de lançamento

Fonte: Torre e Expedicionários (SILVEIRA, 2004), Tambauzinho (A UNIÃO, 1955), Jardim Miramar (PEREIRA, 2008), Bairro dos Estados (COUTINHO, 2004), Conjunto Pedro Gondim (LAVIERI; LAVIERI, 1999), Conjunto Brisamar (SILVEIRA, 2004).

\begin{tabular}{|l|l|}
\hline LOTEAMENTO & ANO \\
\hline Torre & Década de 1937 \\
\hline Expedicionários & Década de 1950 \\
\hline Tambaú & -- \\
\hline Cabo Branco & -- \\
\hline Tambauzinho & Década de 1950 \\
\hline Jardim Miramar & Década de 1950 \\
\hline Bairro dos Estados & 1950 \\
\hline Conjunto Pedro Gondim & 1968 \\
\hline Conjunto Brisamar & 1977 \\
\hline
\end{tabular}

Nos bairros litorâneos, o processo de ocupação residencial, no qual as casas de veraneio tornaram-se residências permanentes, também sofreu aceleração graças à instalação de sistemas de infraestrutura e de transporte, aliado à cultura da praia e do veraneio disseminadas pelas grandes cidades litorâneas brasileiras. De acordo com Silveira (2004, p. 175):

$\mathrm{Na}$ sociedade que ocupou esses espaços, os códigos culturais, ligados à emergência da burguesia industrial/comercial, através do crescimento do mercado de bens e serviços, caracterizam-se pela busca de amenidades, ou seja, a emergência da cultura do sítio de amenidades, posteriormente conduzindo à demanda pela orla marítima da cidade. 
A especulação do preço do solo urbano/habitação deu-se graças à localização privilegiada ${ }^{11} \mathrm{e}$, também, devido ao fato de constituírem símbolos de status e ascensão social. A valorização pelo atributo da amenidade pode ser entendida a partir do que afirma Corrêa (2005):

Os proprietários de terras bem localizadas, valorizadas por amenidades físicas, como o mar, lagoa, sol, sal, verde, etc., agem pressionando o Estado visando à instalação da infraestrutura urbana ou obtendo créditos bancários para eles próprios instalarem a infraestrutura. Tais investimentos valorizam a terra que anteriormente fora esterilizada por um razoavelmente longo período de tempo. (p. 18).

Deste modo, atraídos pelas potencialidades da área, alguns proprietários fundiários de renda mais elevada, até então habitantes de outras áreas mais próximas do Centro, como na Avenida João Machado, construíram suntuosas residências ao longo da Avenida Epitácio Pessoa, sob os preceitos da arquitetura modernista em voga e passaram a residir nelas, frequentando aquele tradicional bairro, apenas para trabalhar ou acessar o comércio e serviço locais.

Lançados na sua maioria entre as décadas de 1950 e 1960, com exceção da Torre e do Conjunto Brisamar, estes loteamentos não possuíam de pronto uma infraestrutura urbana devidamente instalada (Fig. 12). Os serviços de calçamento das vias, prolongamento do sistema de abastecimento de água e de esgoto só foram instalados posteriormente. Esta carência de serviços foi reclamada em matéria jornalística: "Na base do andar da tartaruga, os serviços de implantação dos esgotos sanitários nos bairros de Miramar, Tambauzinho e Torre. Uns já iniciados e concluídos e outros nem sequer iniciados." (A UNIÃO, 01 jan. 1977, p.11).

\footnotetext{
${ }^{11}$ A localização privilegiada da Avenida Epitácio Pessoa decorre da sua proximidade com a orla marítima, assim como do fato de tal via constituir um eixo de fácil ligação com o centro tradicional da cidade que concentrava suas atividades de comércio e serviço. Neste momento, como foi dito anteriormente, a orla marítima torna-se um local de amenidades, de atração da população, valorizando-se.
} 


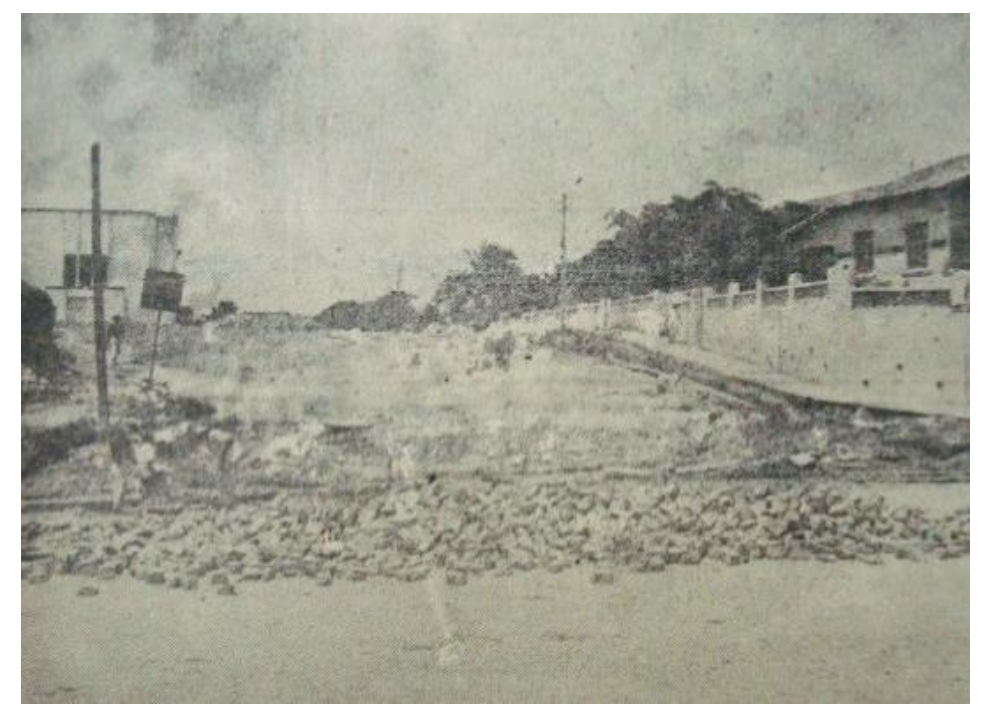

Figura 12 - Obra de calçamento no Jardim Miramar na Rua Hilda Lucena - trecho em frente ao Clube Cabo Branco

Fonte: A União (14 mar. 1959).

Além das residências construídas, é possível destacar também na década de 1950, a construção da sede do Esporte Clube Cabo Branco (Fig. 13). Este clube, fundado em 1915, tinha até então suas atividades esportivas realizadas no bairro de Jaguaribe, sendo transferido na década de 1950 para o bairro de Miramar, devido a uma série de fatores, dentre eles, o interesse do seu presidente - que, na época, presidia também a Caixa Econômica Federal na Paraíba e era responsável pelo financiamento do loteamento Jardim Miramar - em valorizar a área, conferindo visibilidade e atratividade à mesma com a implantação de tal equipamento (PEREIRA, 2008 apud LEAL, 1995).

Após sua inauguração, o clube tornou-se um ponto de encontro da sociedade pessoense e passou a sediar as mais importantes festividades da cidade, com a promoção de bailes, jantares e eventos esportivos, constituindo assim um importante marco da vida urbana de João Pessoa, atraindo ainda mais os olhares para a nova avenida e para o litoral. 


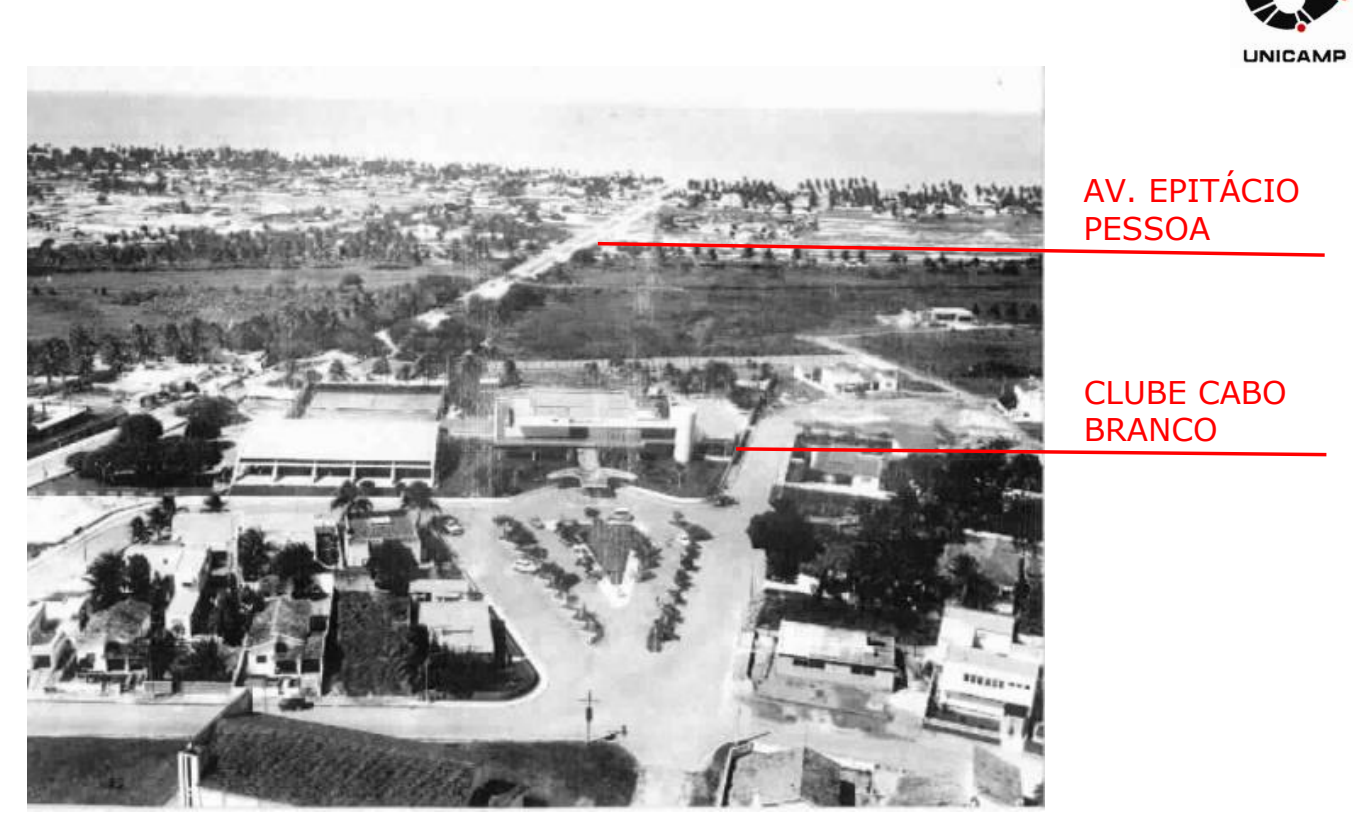

Figura 13 - Imagem do Esporte Clube Cabo Branco (1968) Fonte: Acervo Humberto Nóbrega. Edição do autor (2013).

Desta forma, conclui-se que a ocupação dos lotes localizados na Avenida Epitácio Pessoa, na década de 1950, caracterizou-se por ações pontuais, por meio da construção das residências e estabelecimento dos novos bairros. Realidade que, a partir da década de 1960, passa a ganhar um novo impulso diante de ações políticas voltadas para a expansão da cidade.

Tais ações, por sua vez, repercutiram no desenvolvimento do entorno construído da avenida assim como na sua utilização cotidiana, visto que, além de promoverem a ocupação dos espaços vazios ao longo do seu percurso, agregaram à mesma a função de eixo de ligação à região sudeste da cidade que estava sendo ocupada com os novos conjuntos habitacionais e com a instalação do Campus da Universidade Federal da Paraíba.

De acordo com Carlos (2001), a reprodução do espaço urbano tem como condição a lógica de valorização capitalista a fim de possibilitar os processos de troca, venda e circulação de mercadorias, permitindo a continuidade da produção. A partir da década de 1960, o processo de ocupação da Avenida Epitácio Pessoa passa a sofrer mudanças em consequência dessa produção do espaço capitalista que, por conseguinte,

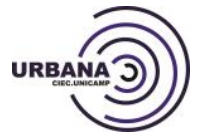

REVISTA ELETRONICA DO CENTRO INTERDISCIPLINAR DE ESTUDOS SOBRE A CIDADE . ISSN 1982-056 v. 7, n. 10, jan /ago (2015). Dossiê História Urbana: a configuração de um campo conceitual 
produzirá uma nova paisagem dando continuidade à reprodução e valorização do capital que as esferas dominantes nela investiram.

\section{Referências}

BENEVOLO, L. História da Cidade. São Paulo: Editora Perspectiva, 1983.

BERMAN, M. Tudo que é sólido desmancha no ar. São Paulo: Companhia das Letras, 2007.

CAPEL, H. La morfologia de las ciudades. Barcelona: Ediciciones del Serbal, 2002.

CARLOS, A. F. A. Espaço e Tempo na Metrópole. São Paulo: Contexto, 2001.

. O Espaço Urbano: Novos Escritos sobre a Cidade. São Paulo: FFLCH, 2007.

CORRÊA, R. L. O Espaço Urbano. São Paulo: Ática, 2005.

COUTINHO, M. A. F. Evolução urbana e qualidade de vida: o caso da Avenida Epitácio Pessoa. 2004. Dissertação (Mestrado) - Programa de Pós-Graduação em Desenvolvimento e Meio Ambiente, Universidade Federal da Paraíba, João Pessoa, 2004.

GUEDES, K. A. O ouro branco abre caminhos: O algodão e a modernização do espaço urbano da cidade da Parahyba (1850-1924). Dissertação (Mestrado) - Programa de Pós-Graduação em Arquitetura e Urbanismo, Universidade Federal do Rio Grande do Norte, Natal, 2006.

LAVIERI, J. R.; LAVIERI, M. B. F. Evolução urbana de João Pessoa - pós 60. In: GONÇALVES, R. C.; LAVIERI, M. B. F.; LAVIERI, J. R.; RABAY, G. (Org.). A questão urbana na Paraíba. João Pessoa: Ed. Universitária/UFPB, 1999. p. 39-66.

LEFEBVRE, H. The production of space. Oxford: Blackwell, 1991.

LEITÃo, D. As ruas de Tambaú. João Pessoa: Departamento de Produção Gráfica da Secretaria da Educação e Cultura, 1998.

MAIA, D. S. Tempos lentos na cidade: Permanências e Transformações dos costumes rurais em João Pessoa - PB. Tese (Doutorado) - Universidade de São Paulo, São Paulo, 2000.

MEDEIROS, C. O Tambiá da minha infância. João Pessoa: A União Editora, 1994.

PEREIRA, F. T. de B. Difusão da Arquitetura Moderna na Cidade de João Pessoa (1956-1974). Dissertação (Mestrado) - Escola de Engenharia de São Carlos, Universidade de São Paulo, São Carlos, 2008.

RODRIGUES, G. Filipéia e outras saudades. João Pessoa: A União Editora, s. d.

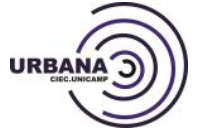


RODRIGUEZ, W. Roteiro sentimental de uma cidade. João Pessoa: A União, 1994.

SÁ, N. L. A cidade da Parahyba e o Movimento Higienista. Dissertação (Mestrado) Programa de Pós-Graduação em Geografia - Universidade Federal da Paraíba, João Pessoa, 2009.

SILVA, M. G. A praia e o imaginário social: discurso médico e mudança de significados na cidade. In: CORRÊA, R. L.; ROSENDAHL, Z. (Org.). Paisagem, Imaginário e Espaço. Rio de Janeiro: EdUERJ, 2001. p. 183-206.

SIlveirA, J. A. R. da. Percursos e Processo de Evolução Urbana: O Caso da Avenida Epitácio Pessoa, na Cidade de João Pessoa-PB. Tese (Doutorado) - Programa de PósGraduação em Desenvolvimento Urbano, Universidade Federal de Pernambuco, Recife, 2004.

SPOSATI, A. (Coord.). Topografia Social da cidade de João Pessoa. João Pessoa: PMJP, 2009. Disponível em: <www.joaopessoa.pb.gov.br/portal/wpcontent/uploads/2012/04/TOPOGRAFIA-SOCIAL-DE-JOAO-PESSOA_2009.pdf>.

Acesso em: 05 mai. 2014.

TRAJANO FILHO, F. S. Do rio ao mar. Uma leitura da cidade de João Pessoa entre duas margens. Arquitexto, São Paulo, 2006. Disponível em: <www.vitruvius.com.br/revistas/read/arquitextos/07.078/298>. Acesso em: 05 mai. 2013.

VIDAL, W. C. L. Transformações Urbanas: a Modernização da Capital Paraibana e o Desenho da Cidade, 1910 - 1940. Dissertação (Mestrado) - Programa de PósGraduação em Engenharia Urbana, Universidade Federal da Paraíba, João Pessoa, 2004.

VILLAÇA, F. Espaço intra-urbano no Brasil. São Paulo: Studio Nobel, 1998.

\section{Fontes Documentais}

Ampliação da rêde de abastecimento de água. A União, João Pessoa, p. 3, 12 jan. 1955.

Aspectos do grande cortejo. A União, João Pessoa, p. 1, 25 dez. 1952.

E a pavimentação continua. A União, João Pessoa, p. 3, 22 out. 1952.

Hoje, o quarto aniversário da atual administração. A União, João Pessoa, p. 1, 31 jan. 1955.

HOLLANDA, Camillo. Exposição do Governador apresentada à Assembleia Legislativa, 1920. 
HOLLANDA, Camillo. Mensagem do Governador apresentada à Assembleia Legislativa, 1917.

Morosidade. A União, João Pessoa, p. 11, 01 jan. 1977.

Prosseguem as obras de calçamento do Jardim Miramar. A União, João Pessoa, p. 8, 14 mar. 1959. 